Open Access

\title{
Dialogic discussion as a platform for constructing knowledge: student-teachers' interaction patterns and strategies in learning to teach English
}

\author{
Lawrence Jun Zhang ${ }^{*}$ (D) and Donglan Zhang(D)
}

*Correspondence: lj.zhang@ auckland.ac.nz

Faculty of Education \& Social Work, University of Auckland, Private Bag 92601, Symonds Street, Auckland 1150, New Zealand

\begin{abstract}
Beginning teachers are frequently heard making observations that the knowledge and skills they have acquired on the training programmes do not come handy when they want to apply them in their real-work situations. They have also reported lacking the ability to integrate theory and practice in reality. Henceforth, teachereducators are faced with challenges of how to proportionally balance the two strands of pivotal knowledge that are necessarily connected with teacher-education curricula in pre-service teacher preparation. One of the approaches to examining the issue is to investigate student teachers' dialogues for knowledge-construction to uncover the interaction patterns and strategies they use in negotiating lesson objectives and processes. Against such a background, this paper reports on a study of 24 student teachers receiving training in English language teaching on the Postgraduate Diploma in Education programme at a teacher education institution in Singapore. It was intended to find out the negotiation processes in relation to lesson-planning objectives and how student teachers positioned themselves and others in the processes in the pre-service teacher-education classroom. Results show that student teachers were more concerned about surviving the first lesson than about promoting pupil learning in constructing knowledge about language teaching. The stronger peers' dominance in the discussion process was taken for granted, suggesting that learning took place in a mutually beneficial and constructive manner and that student teachers' willingness to cooperate and readiness to express themselves were indicative of their intention to maintain group cohesion and dynamics. These, in turn, are necessary prerequisites for student teachers to become collaborative and reflective practitioners.
\end{abstract}

Keywords: Teacher dialogue, Teacher learning, Interaction strategies, Initial teacher education, English language teaching, Singapore (c) The Author(s). 2020 Open Access This article is licensed under a Creative Commons Attribution 4.0 International License, which permits use, sharing, adaptation, distribution and reproduction in any medium or format, as long as you give appropriate credit to the original author(s) and the source, provide a link to the Creative Commons licence, and indicate if changes were made. The images or other third party material in this article are included in the article's Creative Commons licence, unless indicated otherwise in a credit line to the material. If material is not included in the article's Creative Commons licence and your intended use is not permitted by statutory regulation or exceeds the permitted use, you will need to obtain permission directly from the copyright holder. To view a copy of this licence, visit http://creativecommons.org/licenses/by/4.0/. 


\section{Introduction}

The question of how student teachers construct knowledge has been regarded as an important area of professional enquiry in teacher education (van Schaik, Volman, Admiraal, \& Schenke, 2019; see also Clarke, 2008; Deng, 2007; Orland-Barak, 2002; Zembylas, 2003). Accordingly, the teacher education enterprise is expected to contribute substantially to the success of student teachers' future careers upon their completion of training in teacher-education agencies (Borg, 2019; Loh \& Hu, 2019; Richards, 1998). However, beginning teachers are frequently heard making observations that the knowledge and skills they have acquired on the training programmes do not come handy when they want to apply them in their real work. They have also reported lacking the ability to integrate theory and practice in reality (Farrell, 2003, 2008; see also Burn, Hagger, Mutton, \& Everton, 2003; Richards, 2008). Henceforth, teacher educators face the challenge of how to balance proportionally the two strands of pivotal knowledge that are necessarily connected with the curriculum in teacher-education institutions (Edwards \& Mutton, 2007; Hagger et al., 2008). One of the approaches to examining the issue is to investigate how student teachers interact with their peers in the classroom and what kind of strategies they use to solve problems and negotiate objectives while preparing lessons (Johnson, 2007). It is believed that by listening to their dialogues or conversations in their lesson preparation in interactive communication we can have access to their epistemological understandings of learning and teaching. The way they interact with their peers in solving pedagogically-oriented problems can expose them to more situations that emulate real classroom scenarios. This approach is constructivist in nature (Vygotsky, 1987) to the extent that it involves learning through peer interaction and critical reflection (Farrell, 2015; Rytivaara \& Kershner, 2012; Zembylas, 2003), and it will help student teachers to grow professionally.

Furthermore, as Rytivaara and Kershner (2012) argued, co-teaching should be regarded as a context for teachers' professional learning and joint knowledge construction (see also Korhonen, Ruhalahti, \& Veermans, 2019; Ruhalahti, Korhonen, \& Rasi, 2017). Such an argument for giving more responsibility to student teachers and for conducting lessons in a more learner-centred manner would enable student teachers to learn skills. Student teachers can then use these skills in time of need in the immediate future when trainerscaffolding is removed after they graduate from teacher-education institutions (Orland, 2001; Soreide, 2006). This is because it is simply not possible for the teacher-trainer to teach student teachers how to teach individual lessons throughout their lifetime, and student teachers' own exploration into innovation and further expansion of their pedagogical knowledge base will be more relevant to interpreting any syllabus document within which the curriculum is executed in schools (Deng, 2004; Gao \& Zhang, 2020; Jiang, Zhang, May, \& Qin, 2020; Zhang, 2004a, 2016). Thus, the evolving nature of teacher-education, student teachers' needs, and how they construe knowledge are important agendas (Deng \& Gopinathan, 2006; Yuan \& Zhang, 2020; Zhang, 2004b, 2016).

Unfortunately, this important area of discoursal as well as pedagogical inquiry has not been given sufficient attention in language teacher education, especially in Singapore. It is expected that the significance of such an inquiry can shed light on improving teacher preparation practices. Given that teacher education in Singapore has been making great strides in catching up with the latest pedagogies (Deng \& Gopinathan, 2003; Loh \& Hu, 2019; Luke, Freebody, Lau, \& Gopinathan, 2005), we think 
that preservice teacher-education can be one of the platforms that avail us with opportunities to examine existing issues.

Notably, the literature on the nature of talking to learn in higher education has been insufficient (cf. Basturkmen, 2003; Li, Zhang, \& Parr, 2020); even less research has focused on talk among student teachers or their interaction patterns in teacher education settings. The available literature has explored talk in the English-for-academic-purposes (EAP) classroom represented by the teacher and students. For example, Basturkmen (2003), working within the framework of Coulthard and Brazil (1992) on "exchange structures", found distinctive characteristics of interaction with and without the tutor, indicating in particular the greater degree of other-oriented mutuality in the former (see also Hoey, 1992). She argues that such findings obtained from an in-depth analysis of the spoken discourse can provide valuable insights into language description (Sinclair \& Coulthard, 1992).

Basturkmen's review of some earlier work along this line of research suggests that authority figures control talk in a number of specific ways. For example, earlier on, Berry (1981) showed how differences in both knowledge and authority between speakers contributed to different exchange patterns. She found that in the former a number of students did not participate, and virtually only the tutor practised the functions of summarising, rephrasing and making procedural suggestions. In the groups without a tutor, more of these behaviours were practised by students, the ideas were more varied and divergent and the students more likely to express "half-formed" ideas. Lineel, Gustavsson, and Juvonen (1988) investigated unequal encounters. They found that the dominant party controlled initiative-response sequences. Ellis (1999) and Pittman (1999) posit that sequential patterns of interaction reflect course participants' notions of their identities in talk and their concurrence in them (see also Barkhuizen, 2019; Trent, 2012).

$\mathrm{Li}$, Zhang and Parr's 2020) study into the nature of prewriting small-group student talk in Chinese tertiary EFL writing classrooms revealed six categories of focus: Content talk, language talk, task-management talk, organisation talk, affective talk, and phatic talk (p. 1). What is important is that our data showed that such small-group student talk helped EFL learners in several significant ways. It enabled them to generate content, language, and organisation for their proceeding individual writing, provided them with opportunities to facilitate collaborative linguistic problem-solving and use of the first language (L1) for requesting and clarifying information, allowed them to organise the group and scaffold each other collectively to manage the ongoing process of the task, and assisted them to share their emotions and maintain group harmony at a surface level (see also Golombek \& Johnson, 2004).

We expect that in small discussion groups student teachers would also be able to identify themselves through expressing their voice or by taking a personal stance on certain issues while construing knowledge to get lesson planning completed. Also to be revealed in this process of student teacher learning are the sequential foci in their discussion and strategies for negotiating lesson objectives. The strategies used by the student teachers to approach the tasks given would also provide us with insights into their thinking and envisioning about teaching and their self-perceived trajectory to learning to teach. This is because strategies are deliberate, intentional and conscious mental and behavioural actions targeted at solving problems or improving learning (Cohen \& Macaro, 2007). Numerous studies have reported on how language learners use strategies in learning a second or foreign language (see e.g., Zhang, Thomas, \& Qin, 2019; see also Chamot, 2005; Cohen \& Macaro, 2007; Macaro, 2006; Zhang, 2003; 
Zhang \& Qin, 2018). Research studies on general learning strategies also abound (see e.g., Zhang \& Zhang, 2019, for a review). However, in relation to student teachers learning how to teach English, except for a few studies (e.g., Farrell, 2003; Furlong \& Maynard, 2012; Turner \& Turvey, 2002), little is known about how they prepare the lessons not only to survive their first language lesson in constructing knowledge, but also as a way of exercising their identity, of which lesson planning is a precursor and prerequisite (Zhang \& Zhang, 2015).

\section{Knowledge construction in teacher learning}

Student teachers' attempts to construct knowledge about language teaching have much to do with their identity formation and reconfiguration, i.e., their "becoming" teachers (De Costa \& Norton, 2017; Trent, 2012; Yuan \& Zhang, 2020). Drawn on sociocultural theory, a number of scholars interpret teacher education in the framework of the development of a teacher identity (e.g., Clarke, 2008; Pittman, 1999; van Schaik et al., 2019; Varghese, Morgan, Johnston, \& Johnson, 2005). This identity construction process is actually not a linear one, but instead is intertwined among all the participants, and in relation to each and every one of the community with whom the participants work (Barkhuizen, 2019; Trent, 2012; Zhang \& Zhang, 2015). So, this means that identity is not individually constructed by oneself independently of his/her social environment. In learning activities where student teachers are the main participants, it is not only the lecturer who positions them to a certain identity. More often, one's identity is co-constructed with "interested others" (Reeves, 2009).

Obviously, classroom dynamics has much to do with student teachers' emotions in problem solving (Benesch, 2017; Richards, 2020). As recent research findings show, beginning teachers' emotions are exhibited in several different ways. Ria, Seve, Saury, Theureau, and Durand (2003), for instance, reported that beginning teachers experienced contradictory emotions during ordinary teaching; they also reported that the degree to which the teachers depended on their lesson plans was related to the nature of the emotions, which was also related to the need to maintain classroom activities for students. Addressing the construct of "emotion" from a poststructural perspective in relation to teacher education, Zembylas (2003) found that teachers' emotions are closely connected with their identity, showing how emotions are demonstrated as a means of displaying one's identity in teacher education. We wonder how pre-service graduate teachers perceive their roles in sequential patterns of interaction, especially how they use strategies to solve problems to maintain group cohesion and dynamics in achieving their goals of lesson preparation. We assume that student- teachers' emotions also have much to do with their willingness to cooperate and readiness to express their emotions and thinking about teaching with a common goal of planning their first lessons (e.g., Benesch, 2017; Jiang et al., 2020).

Moreover, student teachers' learning trajectory has much to do with how they perceive language teaching processes. This learning process is often spiral and gradually progressive in terms of how much engagement of pupils becomes the focal point in student teachers' lesson planning or related preparation activities for construing knowledge (Fuller \& Brown, 1975; Furlong \& Maynard, 1995; Johnson, 1999; Richards, 1998). It is particularly so when particular cultural contexts are brought into the picture (Zhang \& Ben Said, 2014). Therefore, the present study was conducted to explore the interaction patterns and the strategies of a group of preservice student teachers in the 
way they construe knowledge in negotiating lesson objectives. It is hoped that, armed with this knowledge, teacher educators can deliver the training programme more efficiently.

\section{Methods}

\section{Context of the study}

This action research was conducted as part of a teacher-training programme known as Pupil Experience (PE). PE was initiated as an indispensable component of the English Language teacher education programme in the early 1980s at the then Institute of Education Singapore (IES) and has been revised and updated several times after IES was reshuffled to form the National Institute of Education (NIE) as a school of the Nanyang Technological University. As a replacement of "micro-teaching", it has been in place since then. It comprises six 2 -h preparation sessions at NIE and six corresponding teaching sessions in the school. It is part of a teaching methods modular course but conducted prior to student teachers' full participation in the module. In the preparation sessions the trainers and the student teachers discuss issues ranging from classroom management to the actual delivery of English Language lessons. However, the trainer acts as a facilitator at most, i.e., student teacher learning takes place in a constructivist framework. PE is sequenced in such a way that student teachers are expected to realise the rationale of how all the sessions are prepared and conducted. Although it is not a rigid regime and lessons are not confined to discrete skills, a sequential breakdown of the PE programme shows that the following is typical: getting to know your pupils; teaching listening; teaching reading; teaching oral communication; teaching writing; teaching grammar; and summing it up (see Skuja-Steele, 2004, for details).

\section{Objectives of PE}

One of the major objectives of PE is to help student teachers to understand pupils through a sheltered approach so that these student teachers will better appreciate the training programme professionally once they start taking the methods-oriented modules as well as to understand teaching in reality. As is clearly laid out in the Pupil Experience Workbook (Skuja-Steele, 2004), "PE is a sheltered introduction to the realities of the classroom. It will help you [student teachers] to better understand lesson planning and presentation and your pupils as learners" (p. 2).

Another objective is that, through a sheltered approach, student teachers are expected to hone skills as learners themselves in collaborative learning and cooperation in the classroom. According to Oxford (1997), cooperative learning, collaborative learning and interaction are three communicative strands in the language classroom (see also Kagan \& Robertson, 1993; Ruhalahti et al., 2017). This suggests that in teacher education similar understanding should be pursued so that student teachers will be well informed of what it means to teach language as communication (Benesch, 2017; Clarke, 2008; Rahimi \& Zhang, 2015; Turner \& Turvey, 2002; Zhang \& Zhang, 2018). Therefore, it is expected that upon graduation from the training programme they are better equipped to efficiently solve problems that might surface in teaching when they are placed in real-life situations in schools. 
PE regards classroom dynamics as the third major objective. It is hoped that student teachers can experience this crucial aspect and their personal learning expectations in the school will become an asset to their teaching in the future. The above-mentioned areas are complicated and we believe that PE as an important bridge that has the potential of inducting the student teachers to the real classroom will reveal significant findings as an avenue to understanding student teachers' effort in learning to construct knowledge, especially in relation to how to teach.

\section{Research questions}

Ellis (1999) and Pittman (1999) posit that participants' understanding of themselves in talk is reflected in sequential patterns of interaction. Reflected in teacher education will be the sequence in which specific topics are proposed as points of departure in student teachers' effort to work out lesson objectives through the deployment of various strategies in problem solving. With this overall aim in mind, we addressed the following questions.

1) What interaction patterns emerged from classroom group lesson-planning discussions for constructing knowledge in negotiating lesson objectives?

2) What strategies, if any, did student teachers use to solve problems during lessonplanning discussions for constructing knowledge in negotiating lesson objectives?

3) Are there any conceptual changes in student teachers in the course of constructing knowledge about learning to teach in the classroom?

\section{Participants}

Twenty-four student teachers studying on the one-year full-time Postgraduate Diploma in Education Programme specialising in English Language teaching (PGDE-EL), an initial teacher-education programme at a teacher education institute in Singapore, were invited to participate in this study. An information sheet distributed and collected in the first session of the programme shows that all of them earned a Bachelor's Degree in English Literature, but only seven of them had experience in classroom teaching either as contract or as relief teachers in various government schools in Singapore. These student teachers, who had undergone schooling in English in Singapore, were receiving training in two curriculum subjects (CS) assigned to them by the Ministry of Education of Singapore: English Language as the second curriculum subject (CS2) and English Literature as the first curriculum subject (CS1). These student teachers were strong in English Literature and were highly proficient users of English because they had completed their education in English as the medium of instruction since nursery school in Singapore. Due to a greater demand in the schools for English Language teachers, the MOE assigned them to teach both English Literature as their CS1 and English Language as CS2. They had to complete related teaching methods courses that would prepare them to teach English Language and English Literature. The study reported here focused on their training experience in becoming English Language teachers.

When asked, none of them said that they had the confidence in teaching English Language, as they said that they did not have sufficient training in English Linguistics or English Language Studies and therefore did not have a very strong background in 
linguistic description of English, especially explicit metalanguage to describe English grammar. Their average age was 24 years. As is the norm in teacher training in Singapore and as expected, the majority were women and only three were men. For the purpose of conducting PE sessions they were divided into six groups, with each group comprising four student teachers.

For the convenience of reporting, we focus on one discussion group. All of the participants were women, with their ages ranging from 23 to 26. They had gone through 7 weeks of School Experience (SE) prior to PE. SE is a required component of the NIE initial teacher training programme for all the PGDE students. According to the requirement stipulated by the NIE Foundation Programmes Office, an office in charge of preservice training programmes, all student teachers are posted to schools to go through SE and each student teacher is assigned a school mentor (SM) and two cooperating teachers (CT). One NIE supervisor also collaborates with the school for the SE programme in helping the student- teachers complete SE.

From both what the student teachers have said and what we have observed as SE supervisors/mentors, we understand that the student teachers are usually not given enough time to conduct classroom teaching during their SE. The major objective of SE is to help the student teachers to get immersed in the school environment and observe how teaching occurs. They are expected to start reflecting on how they do the teaching so that, when they return to the training agency, they will know how to relate theory to practice. We chose this group to report on because the all tutors/researchers involved had agreed, on the basis of examining their field notes, that the group was quite cooperative.

\section{Sources of data}

The study was based mainly on qualitative analyses of audiotape recordings of preservice student teachers negotiating their lesson objectives and roles in problem-based learning environments while preparing themselves for peer-teaching activities that were to happen in real classrooms in a local neighbourhood government-funded secondary school. Tutor/Researcher observations, field notes and student teachers' reflective journals were used to triangulate the data. Data were collected from all the participants in six 2-h sessions where they were required to negotiate possible pedagogical solutions to the instructional materials they had been provided with in terms of the lesson objectives and how they would be implementing them. Three 2000-word journal entries were collected from all student teachers every 2 weeks as assignments to satisfy the requirement of a 54-h course titled "Approaches to Language Teaching" that ran for one semester. These journals were also taken as a source of the data for this study.

For the sake of continuity and for the purpose of investigating the links among these six sessions, we audio-recorded all six preparation sessions. Field-notes were taken as complements in case of uncertainty in triangulating the data. Each group was provided with an audio recorder. They had been clearly explained the procedures in using the equipment. The moment they started talking about lesson planning or the prelude to this important part of the preparation session, an elected group leader was reminded to turn on the recorder and set it in the recording mode. Their group discussion was not interrupted although the first author/researcher went around in the classroom to take 
notes of important episodes in their discussion. Occasionally, if a question arose from the students, the researcher answered it, which might have temporarily interrupted the discussion albeit in a related manner. During observations, we took detailed notes that charted attendance, role assignment dialogues, interpersonal relationships, and the course of activities and student teacher participation patterns, paying special attention to discussion in order to find out how student teachers negotiated knowledge about language teaching and learning.

\section{Data analysis}

Richardson (1999) notes that student-centred curricula intended for student-directed learning have become focal points for constructivist-based educational practices. Recent work has also reinforced this is the case (see e.g., Dikilitaş \& Hanks, 2019). Therefore, in analysing the data, we had two major concerns in mind. One was how participant initiations contributed to the development of ideas, and the other what strategies were used to solve problems that had been uncovered. In other words, our data analysis was a content analysis (Miles \& Huberman, 1994). Our focus was on qualitative data, taking the two major concerns: interaction patterns as expressed in their topical and sequential focuses and their strategies. These two aspects were taken as the framework within which categorisation of the data was executed.

Following Miles and Huberman's (1994) suggestions, we examined two major sources of data in great detail: Transcribed audio-recordings and field notes. We cross-checked the data, as cross-checking of the data was deemed as a necessary measure to guarantee validity. While analysing the data, we listened intensively to the discussion in the first two sessions of the audio-recordings and started noting the major trends or typical patterns emerged. For the other four sessions, we listened mainly for finding corresponding sequences and connections among the sessions. In analysing the data, we looked for typical patterns independently and based on what we found, we gave a code for each. The two researcher/lecturers then compared the coded data and cases of disagreements were solved though discussion. The final agreement reached $85 \%$. In order to save space, the coding scheme and the definitions of each strategy (see Table 1) are reported when we report findings in the following section. Our ultimate expectation was to see how the student teachers constructed knowledge and grew in their understanding of the pupils, their learning processes and other issues related to language teaching, how they regarded themselves and their relations with their peers as a way of showing their identity, especially in relation to the operationalisation of the lesson objectives.

\section{Findings}

We report our findings from two aspects relating to how student teachers constructed knowledge about learning to teach English, which will be taken as our frameworks within which the data are organised. These two aspects are: 1) topical sequence and focus, and 2) problem-solution sequence, viz., strategies used in solving problems. We do so because we found that all these two themes recurred in all the six sessions, lasting $12 \mathrm{~h}$. For the sake of convenience and systematicity, we report on the topical sequence and focus under one heading. 
Table 1 Strategies, substrategies, their definitions, and typical cases of strategy use by student teachers in dialogic lesson-planning discussion

\begin{tabular}{|c|c|c|c|}
\hline Strategies & Substrategies & Definition & Example \\
\hline \multirow[t]{2}{*}{$\begin{array}{l}\text { Defining } \\
\text { procedures }\end{array}$} & Pro-nar & $\begin{array}{l}\text { Narrating what they will be } \\
\text { doing in the lesson }\end{array}$ & $\begin{array}{l}\text { Just let them call me Mrs. Ravi. I don't need } \\
\text { one Indian student to make fun of my name. } \\
\text { I'll write my name on board. }\end{array}$ \\
\hline & Pro-cla & Making clarifications & $\begin{array}{l}\text { "Who's going to observe the pupils?" "You see } \\
\text { you can take turns, you know." }\end{array}$ \\
\hline \multirow[t]{5}{*}{ Organising } & Org-tim & Organising time & $\begin{array}{l}\text { "You know you can take a bit less because the } \\
\text { Icebreaker is not your focal point." }\end{array}$ \\
\hline & Org-tas & Organising tasks & $\begin{array}{l}\text { "No, I think it's better for her to do the } \\
\text { Icebreaker because the next session after mine } \\
\text { is yours." }\end{array}$ \\
\hline & org-mat & Organising materials & "Maybe I don't need this idea of punishment." \\
\hline & Org-res & Organising resources and aids & $\begin{array}{l}\text { "The tape-recorder must be a really powerful } \\
\text { one. It can't be this one. Bring our own." }\end{array}$ \\
\hline & Org-spa & Organising space utilisation & $\begin{array}{l}\text { "We have } 16 \text { pupils. Are we going to put the } \\
\text { chairs and desks in a semicircle?" }\end{array}$ \\
\hline \multirow[t]{2}{*}{ Rehearsing } & Reh-ora & Rehearsing oral teacher talk & $\begin{array}{l}\text { "Then we will just gradually move on to the } \\
\text { next set of questions. We'll say, 'so you will } \\
\text { pick and read the questions themselves or we } \\
\text { will just take it from them and we ask." }\end{array}$ \\
\hline & Reh-que & Rehearsing questions & $\begin{array}{l}\text { "We need to read out the questions. 'Who's } \\
\text { your favourite star?"" }\end{array}$ \\
\hline \multirow[t]{3}{*}{ Reviewing } & Rev-rec & $\begin{array}{l}\text { Recapitulating what has been } \\
\text { discussed so far, usually to arrive } \\
\text { at a consensus }\end{array}$ & $\begin{array}{l}\text { "After Icebreaker come out and talk to the } \\
\text { whole class. Icebreaker we don't need to do or } \\
\text { write anything." }\end{array}$ \\
\hline & Rev-wok & Checking workbook guidelines & $\begin{array}{l}\text { "So you have a set of questions that you're } \\
\text { supposed to write, right." "Where is it?" "Page } \\
28 \text { [PE Workbook], case study instructions." }\end{array}$ \\
\hline & Rev-cor & Correcting & $\begin{array}{l}\text { "No, no, this is not the two people. It's when } \\
\text { they would be writing. This is different. Here } \\
\text { you just observe as many as you can, what } \\
\text { their response is." }\end{array}$ \\
\hline \multirow[t]{3}{*}{ Anticipating } & Ant-the & $\begin{array}{l}\text { Anticipating a future scenario (if- } \\
\text { then) }\end{array}$ & $\begin{array}{l}\text { If students come in a bit early start giving } \\
\text { them files and name tags instead of being so } \\
\text { rigid_-can save time." }\end{array}$ \\
\hline & Ant-cav & $\begin{array}{l}\text { Anticipating caveats regarding } \\
\text { plans }\end{array}$ & $\begin{array}{l}\text { "Don't worry too far. Play by ear. This one ok." } \\
\text { Depends on class, not now." }\end{array}$ \\
\hline & Ant-res & Anticipating results or outcomes & $\begin{array}{l}\text { "At least we know whether they want to talk } \\
\text { or not." }\end{array}$ \\
\hline
\end{tabular}

\section{Topical sequence and focus}

When the group discussion for knowledge construction was investigated, we focused on strategies used by the student teachers in relation to group dynamics and relationships among the members. We found that that there was cooperation and peer support necessary for this kind of discussion to continue. Each group member managed to contribute to the discussion, trying to make sense of English Language teaching from the very first session. However, the uneven contributions from group members seemed to be a quite common feature. From the way they initiated a topic, took turns to address it in order to maintain topic continuity that was geared at problem-solving, we found that they were collaborating for a common goal, working towards lesson planning objectives. It is clear that they were on task. This is why their focus on topic sequence turned out to be a common recurring theme throughout the six preparation sessions. 
We start with lesson one, which focused on "getting to know you". In this preparation lesson conducted on Monday, the student teachers were briefly explained the rationale of the PE programme. Then they had to start preparing for their first session they were going to teach the coming Saturday. This was their very first preparation session, but the student teachers seemed to have well-imbibed the idea of what was stated in the PE Workbook. Starting from logistic considerations such as getting name tags ready so that pupils would not address them wrongly and hence avoid the embarrassment, they went on to explore what other aspects were involved in the first lesson. Concerns over ways of greeting and attires expected of pupils were brought up in their discussion.

By referring to the PE Workbook, the student teachers realised that an attendance sheet had to be prepared for the class so that they could start checking on pupils' turnup rate. They regarded having pupils' telephone numbers as necessary for future sessions. When they started working on the icebreaker segment, which was the key part in the first session, followed by the speaking diagnostic component which was supposed to serve the purpose of helping them to know their pupils, they thought of using a game. As they were aware, by cultivating student interest in English, they hoped that students would start showing their interest in English not only as a curricular subject but also as something that was relevant to their social lives, given that English is the most commonly used official language in Singapore.

Indeed, they knew that PE served the purpose of helping weaker pupils to catch up with their English learning. Their thinking was centred on whether or not they should explicitly tell the pupils that PE was a programme where the pupils as learners of English could find in which areas they were strong and/or weak. After some discussion, they all agreed that they should make this learning objective clear, as is shown by the segment of the data below.

\begin{tabular}{lll}
\hline $\begin{array}{l}\text { Turns } \\
\text { Student } \\
\text { teacher }\end{array}$ & Dyads in discussion \\
1 & Ann: & $\begin{array}{l}\text { This is almost the time for us to introduce the PE programme to the pupils. Should we } \\
\text { say that this PE is especially for them and it is an EL Enrichment Programme? }\end{array}$ \\
2 & Jane: & $\begin{array}{l}\text { I think so. } \\
3\end{array}$ \\
Ann: & $\begin{array}{l}\text { Maybe it is ok to introduce it as an English enrichment programme where they can find } \\
\text { their weaknesses and strengths. }\end{array}$ \\
& Angie: & Ok.
\end{tabular}

In order to "kick off" the lesson on a cheerful note so that pupils could be motivated, they were discussing when they should administer the "Language Learning Survey" required in the PE Workbook, which was intended to elicit information on pupils' attitudes to English and their problem areas. They also thought of using the audiorecorder to help them establish teacher-pupil rapport. Typically, the sequence of thinking found can be represented in this way (see Fig. 1).

In clarifying their roles by focusing on their prospective tasks, the student teachers were making an effort to make sense of their first English Language lesson. The first thing that they thought of was how to mobilise pupils to establish a right rapport with them. In more ways than one, it seems that they were more concerned about selfsurvival than how to help pupils to learn. As explained in the PE Workbook, one of the activities was the icebreaker activity that used the "musical chair" game. They did not 


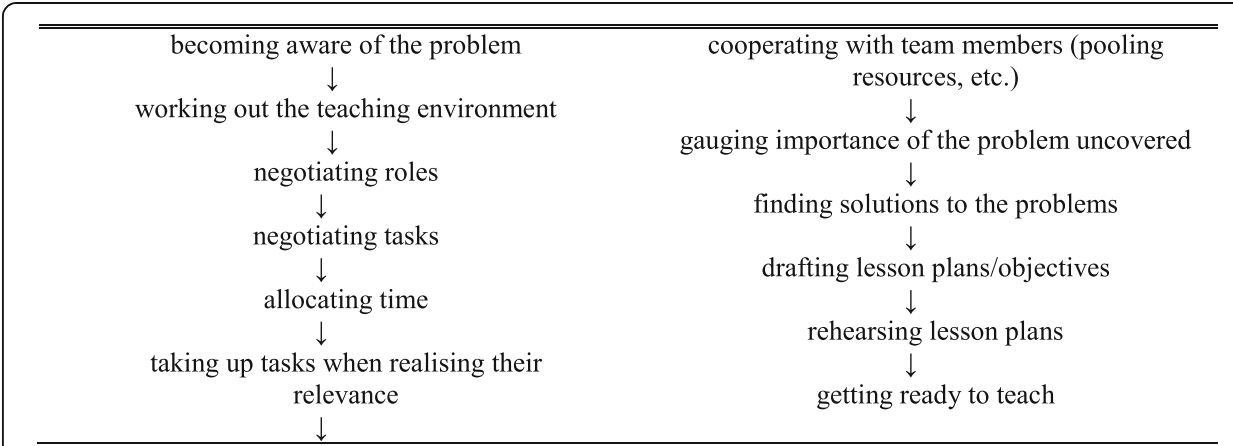

Fig. 1 Sequence of Thinking in Student teachers' Lesson Planning Discussion

have difficulty in understanding how the game should be implemented. They were more concerned about which teacher should take charge of it.

It is evident that Ann was proactive and she stepped in to take control of the situation by acting as the organiser of the group discussion. Of course, it was she who was going to lead the whole class for the rest of the session. To a great extent, she was showing her essential qualities as a potentially successful teacher. Nevertheless, it is only fair to say that, like the other three members of her group, she was also very much concerned about how to project her image in front of the class, so rapport building became a focal point for her.

\begin{tabular}{|c|c|c|}
\hline Turns & $\begin{array}{l}\text { Student } \\
\text { teacher }\end{array}$ & Dyads in discussion \\
\hline 1 & & $\begin{array}{l}\text { So, have you decided who is going to do the icebreaker? I think it is better for all of us } \\
\text { to do the icebreaker, because the next session after mine is yours so that you can } \\
\text { gradually take it over instead of, you know... }\end{array}$ \\
\hline 2 & & $\begin{array}{l}\text { Instead of me not knowing what to do ... things will go complicated, and I think it's } \\
\text { good I come in earlier. }\end{array}$ \\
\hline 3 & & Ah ... so you can do the icebreaker, ok, then, and you have a list of my questions, right. \\
\hline 4 & & Ok. So we can take turns... \\
\hline 5 & & $\begin{array}{l}\text { So basically the groups will be dreaming where they are, and then I will ask the } \\
\text { questions and Angie will be taking down for observations and you will be taking down. } \\
\text { But do we know what we are supposed to do? Take down? There is diagnosis } \\
\text { worksheet. }\end{array}$ \\
\hline 6 & & Yeah. \\
\hline 7 & & We have to make enough copies of it $a h$. \\
\hline 8 & & There should be. \\
\hline 9 & & $\begin{array}{l}\text { But I don't know if it is enough, you know. We are writing, you know. Maybe we write in } \\
\text { foolscap, later we... }\end{array}$ \\
\hline 10 & & Is it writing? \\
\hline 11 & & This one, is it? \\
\hline
\end{tabular}

Obviously, Ann was taking a leadership role in the first session, as is evidenced from the beginning of the first discussion session (turn 1 onwards). Her identity as a successful teacher and leader of the group was brought out all clearly. She was the organiser of her group's discussion and she was also the one who gave chances to her members to choose their own roles so that they could take charge of the component 
that they were supposed to perform well in front of so many new faces (pupils). When her role was well prepared, she handed the responsibility to Angie, who was then to take the lead in the discussion on how the "listening diagnosis" segment was to be implemented. In this case, Angie did not feel that she was subjugated in the whole organising process possibly because all the members were so engrossed with making the discussion as productive as possible so that clear lesson procedures and lesson objectives were in place.

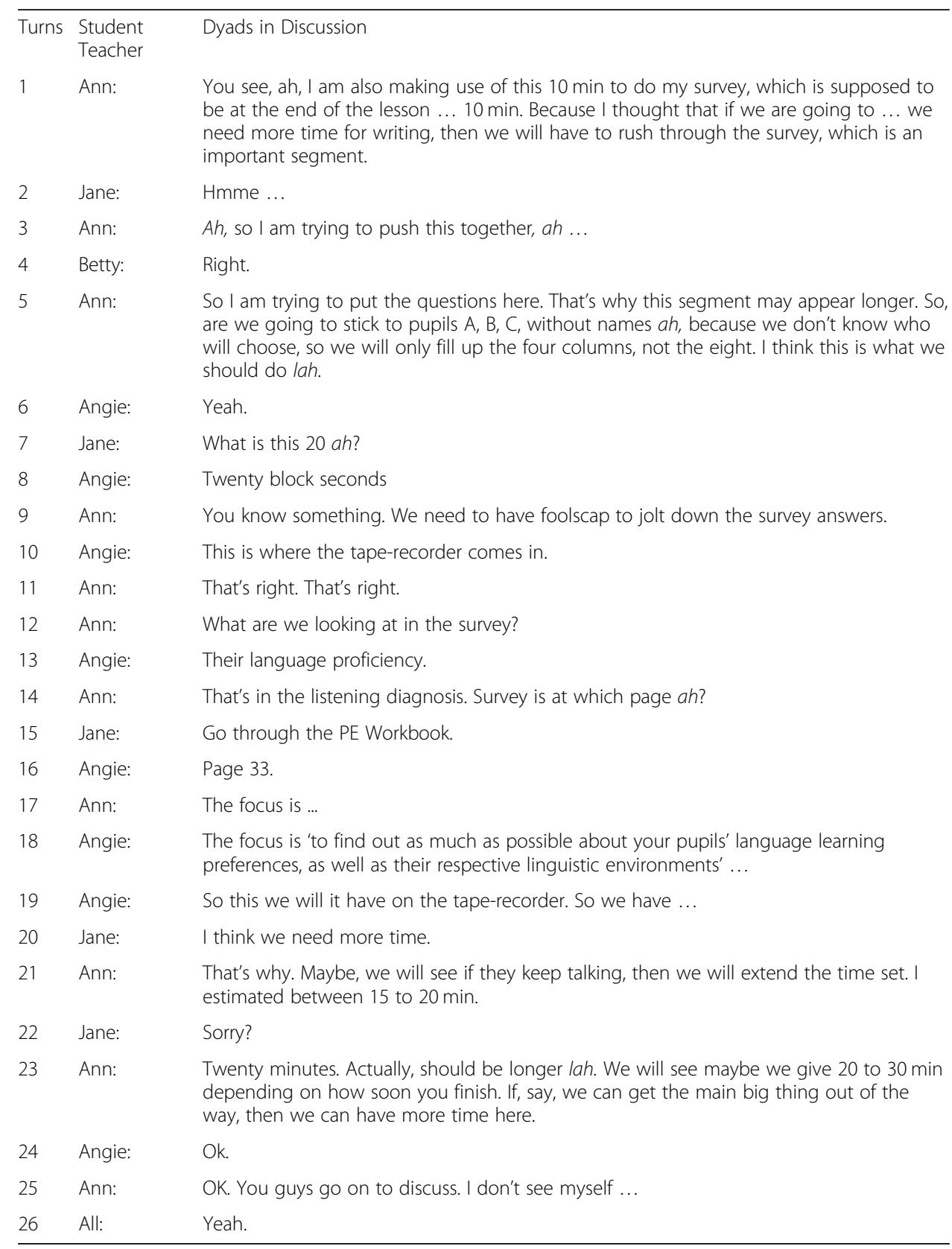

Problem-solution sequence

Strategies are deliberate, intentional and conscious mental moves or physical action geared at solving problems or improving learning (Chamot, 2005; Oxford, 
2017). The interaction patterns became quite obvious when the student teachers mentioned specifically the steps they wanted to take to solve their problems identified along the way. These strategies were also sequentially presented, though not all the time consistently. The student teachers' use of strategies showed their knowledge and experience that they brought to bear in the process of their finding lesson planning solutions, especially in relation to lesson objectives. Planning for teaching each of the PE sessions was considered to be the overall goal for each of the taped group conversations. Subsumed under "planning", five areas of focus were identified: 1) defining procedures, 2) organising, 3) rehearsing, 4) reviewing, and 5) anticipating. Table 1 is a summary of these strategies elicited from the student teachers' discussion.

As we can see in Table 1, when the student teachers started their planning, they were trying to define what procedures should be followed to start a new class. They were unsure of what kind of pupils they would have in their PE lessons. As their planning progressed, they paid more attention to time, tasks, materials, resources and aids, and classroom space utilisation. Rehearsing what was planned in order to be successful in their first lesson was not overlooked. After some discussion, the student teachers also realised that they needed to review what had been discussed by recapitulating it in order to arrive at a consensus. To do so, they checked their PE Workbook guidelines, and once they found they were wrong, they took corrective measures.

As can be easily understood, getting ready for the first lesson is an excitingly daunting and anxiety-driven task. Therefore, anticipating a future scenario and caveats is natural, and this is exactly what was found in the discussion. Angie said, "if students come in a bit early, start giving them files and name tags instead of ... not being so rigid ... can save time." Betty said, "at least we know whether they want to talk or not". However, they were not sure what results or outcomes were expected in terms of achieving the explicit lesson objectives.

Interestingly, these strategies were used in their very first lesson preparation session, and as expected, their awareness of these strategies and of their suitability in particular skill areas (listening, reading, speaking, writing and grammar lessons) increased as the PE preparation progressed over a period of 6 weeks, involving 2-h preparation sessions with the tutors each week. A rough comparison of the strategies they used suggests that, as they progressed from session one to session six, they started to monitor their growth of knowledge and their intended solutions were not only at the level of typical logistics level. Instead, because of the previous preparation sessions, their professional knowledge grew thanks to the number of preparation sessions and their own in-class teaching through direct contact with school pupils.

While preparing for their first session, they were told clearly that the focus was on getting to know pupils, their prospective students. Therefore, their concerted effort was on how to implement the material given to them. Angie, in addressing her concerns over how to use the text on "punishment" provided in the PE Workbook, she started sharing with her group members what she thought would be a better solution to the problem she had perceived. 


\begin{tabular}{|c|c|c|}
\hline Turns & $\begin{array}{l}\text { Student } \\
\text { teacher }\end{array}$ & Dyads in discussion \\
\hline 1 & Angie: & $\begin{array}{l}\text { Actually, I don't know the idea of punishment is going to be useful. I'm going to talk to } \\
\text { them about punishment and I am going to tell them that ... I am not going to tell them } \\
\text { the part that they are going to write about it later so that if they don't like it, I don't have } \\
\text { to worry about it; they still can follow me and enjoy writing it. I don't want them to } \\
\text { know that this is what they are going to write about. }\end{array}$ \\
\hline 2 & Jane: & Ok, good. \\
\hline 3 & Angie: & $\begin{array}{l}\text { Ok, I will share some experiences of mine so that they know about it. I am certain I have } \\
\text { the ability of all men to do that, introducing 'punishment' and my next experience or } \\
\text { something, and I will try incorporate talk of other ways. I will give something that sounds } \\
\text { different to them. This might be good for me to control the class better. }\end{array}$ \\
\hline 4 & Angie: & $\begin{array}{l}\text { Maybe I will get a ... a ... ah ... very general ... things like punishable or not } \\
\text { punishable, punished before, which definitely, is not an issue. Of course, all of us know } \\
\text { about it. }\end{array}$ \\
\hline 5 & Ann: & That's good. \\
\hline 6 & Angie: & $\begin{array}{l}\text { Then, I will talk about what things have been done that constituted ... which led to the } \\
\text { punishment, what sort of punishment? It's a kind of things which you can later develop } \\
\text { on it, all right. This is one of the questions that I have come up with, and I am sure a } \\
\text { couple of people, something that is useful to our lesson. I think that's all about it. This is } \\
\text { the part that I am taking. The other, I will be telling, ah ... I am going to introduce to } \\
\text { you a passage about punishment. I am going to give the entire passage first. }\end{array}$ \\
\hline 7 & Betty: & Ok. \\
\hline 8 & & $\begin{array}{l}\text { Then I'll be telling. I've picked up a hundred words. It's not going to start with the first } \\
\text { hundred words. That is only for one day. They will have to look at it. Three nights before } \\
\text { that. Two or three words ... then they will write on 'punishment'. So we will start writing } \\
\text { our lesson plan. }\end{array}$ \\
\hline 9 & Ann: & Do we need to rehearse it? \\
\hline 10 & Angie: & I am not so sure. But let's first go over our lesson. \\
\hline 11 & Betty: & I think it's good to rehearse it before we teach it. \\
\hline 12 & Angie: & Ok, then. \\
\hline 13 & All: & Ok. It seems that it is ok now. \\
\hline
\end{tabular}

In this segment of the first preparation session, Angie, who was the person charting the preparation of the listening diagnosis, a dictation exercise, seemed to be quite comfortable in handling the problems. Maybe because of her overbearing attitude, or at least, the way that she was capable of using English suggests this, her group members simply showed their endorsement for the strategies adopted. Only occasionally did other members ask for clarification. Ann, who was very active in the first segment of the discussion, also subsided because she had realised that her role was over. Her presence in the group was to support and provide feedback on what the other member was planning. Fortunately, they finally agreed with the proposed plan of lesson objectives and how this plan could be tried and implemented.

When the group met on the second Monday, after the tutor/researcher explained the major objectives of the session, which was to prepare for a listening lesson using the materials provided, the group members became active again. Among the members they were negotiating roles and the materials. Of course, this session was more valued by the student teachers because they had already had some "real" experience in the school. So their preparation was more geared towards the "realities" of the school and the respective pupils about whom they had known something. Their discussion also showed their incorporation of the information they had collected in their first session: Pupils' proficiency level, motivation to learn English, attention spans, and the 
predominant language they used with family members at home and with their peers. All this seemed to be important information that helped the student teachers' planning.

It appeared as well that, because of their valuable experiences in the first and second sessions, by the time they were preparing for their third, fourth, fifth and sixth sessions, their confidence increased proportionately due to their gradual understanding that teacher control was of primary importance, which they were finally able to achieve. At the end of the PE programme when a sharing cum debriefing session was held, many of the student teachers realised how classroom dynamics functioned to contribute to success in teaching and learning. As Jane said:

Learning a language involves a conscious effort on the part of the student. Our own enthusiasm for English and for having fun in the language is transmitted to the children, who in turn decide they love being in school and learning English.

Ann's reflection on her own experience similarly suggests how much benefit she gained from the PE teaching experience. She said:

I feel that PE is a valuable teaching and training aid cum experience, as it emphasised the importance of interrelating speaking and listening, reading and writing and of providing an integrated curriculum. We had to adopt a holistic approach, encouraging participation and exploration, for self-directed learning is far more effective than memorisation of fact [s]. As pupils' and their perceived needs, proficiency levels and objectives change, so will the contents and techniques of language teaching. Teaching is an ongoing process. Strategies will evolve and teachers will have to adapt. Still, I am hopeful that the experiences and principles I have derived from PE will serve as a useful springboard for future teaching.

While commenting on her PE experience, Betty equally found something profound. She understood from the limited classroom experience she had got that the methodology for delivering the material was as important as the material itself. To quote her comment:

I have learnt that the choice of appropriate material is a major concern for the teacher but what mainly matters is not only the material itself but the use of the wider range of apparatus that the methodological approaches offer. In other words, what really makes the difference is less the material and more its treatment by the teacher. PE definitely has changed my view on the teaching of English; it has fuelled my passion for the profession.

The gradual progression in the student teachers' understanding of the teaching process that was regulated by the way the lesson planning was negotiated similarly suggests that, because of the exposure to the teaching scenarios, the student teachers demonstrated their readiness to accept a professional attitude towards lesson preparation. Angie's journal segment further illustrates what the importance of getting lessons prepared means to the student teachers. 
Our first lesson plans were very general and vague and we were sceptical of the necessity of it being detailed. However, they soon became an essential guide. Besides using them for time management and as [a] reminder of the sequence of activities to follow, they also got us out of possible problems for they contained contingency plans.

We understand that learning to teach involves many faceted experiences, one of which is how student teachers understand their pupils. At this point, it seems that what was taught in other educational modules also helps them realise that teaching does not only entail teachers' delivery of knowledge; instead, it is an interactive process where pupils need necessary scaffolding in their learning experiences. This kind of observation came from student-teachers. For example, Tom had this to say:

Scaffolding is imperative in helping students achieve the learning objective. In writing, for instance, the pre-writing activity helped students to formulate ideas and structure their thought processes before performing the main writing exercise. Scaffolding is especially necessary when the subject matter is unfamiliar. Scaffolding essentially means helping students performing a task by doing some work for them in the initial stages. This aid is however, meant to be only temporary, which means that it has to be eventually removed. This method helps to develop what Vygotsky calls students' "zone of proximal development".

Also interesting is that those student teachers gave attention to the topics and aspects that were typically present in many student teachers' first lesson. In most of the lessons, for example, the topics and aspects they touched on started from greeting the class. Their lessons ended in reviews of observation tasks or with other teacheroriented tasks such as requiring pupils to write something. Table 2 is a summary of typical classroom procedures observed in the lessons.

It has to be pointed out that, although they really grew in their concern over the procedures and steps in planning and organising their lessons, their attention to pupils did not increase accordingly. This finding lends support to what Fuller (1969), and Furlong and Maynard's (1995) study of beginning teachers in many ways. According to

Table 2 Topic and sequence in student teachers' lesson-planning discussion

\begin{tabular}{|c|c|c|c|}
\hline \multicolumn{4}{|c|}{ Topic/Aspect Sequence in Dialogic Discussion } \\
\hline 1. Greeting class & 2. Text copies & 3. Desk arrangement & $\begin{array}{l}\text { 4. Beginning } \\
\text { lesson }\end{array}$ \\
\hline 5. Introduction & $\begin{array}{l}\text { 6. Appropriate wear for } \\
\text { pupils }\end{array}$ & 7. Name tags & $\begin{array}{l}\text { 8. Attendance } \\
\text { sheet }\end{array}$ \\
\hline $\begin{array}{l}\text { 9. Review of status and timing so } \\
\text { far }\end{array}$ & 10. Early pupils & $\begin{array}{l}\text { 11. Teachers and } \\
\text { groups }\end{array}$ & 12. Observation \\
\hline 13. Lesson focus & 14. Future lessons & 15. Questions & 16. Time \\
\hline 17. Teacher talk & 18. Icebreaker & 19. Observation & 20. Survey \\
\hline 21. Time & 22. Punishment (dictation) & $\begin{array}{l}\text { 23. Punishment } \\
\text { (writing) }\end{array}$ & 24. Writing \\
\hline 25. Observation task & $\begin{array}{l}\text { 26. Review of observation } \\
\text { task }\end{array}$ & & \\
\hline
\end{tabular}


Furlong and Maynard (2012), for example, student teachers have difficulty in shifting their attention away from teaching to pupil learning because of two reasons: they have their own views and beliefs about teaching and learning and they lack confidence in classroom management and control, which does not give them enough room for experimenting other approaches that would possibly more favourably benefit pupil learning.

\section{Discussion}

Preservice teacher education is a huge enterprise in every education system and it is no exception in Singapore. As the sole teacher education institution, NIE has shouldered heavy responsibilities in the process to pursue excellence, i.e., towards an institute of distinction (Loh \& Hu, 2019). English Language teacher education for that matter has been endowed with an even more important role in the education system, where English is stipulated as the medium of instruction in a non-native speaking environment. Success in English as a curriculum subject is crucial to the pupils' future (Silver \& Bokhorst-Heng, 2016). The PE programme is one of the approaches to developing student teachers' competencies in the areas in which they specialise. Given that PE is driven by the principle that teacher preparation is education as compared with training (Deng \& Gopinathan, 2006), this principle is in line with what Vygotsky (1987) terms the interplay between formal knowledge of principles and knowledge gained through activity, through which people will think about problems beyond their range of experience. In this sense, it can be speculated that what we have found in the PE programme is meaningful in at least three ways.

Firstly, while our findings suggest that empowering students through guided practice has its significance in the Singapore context, the notion of teacher education vis-à-vis teacher training seems pivotal (Deng \& Gopinathan, 2003). Essentially, PE has been intended to induct student teachers into the profession of English Language teaching. It is hoped that after PE they will be able to cope with contingencies on their own and, through collaboration, they are expected to hone their own management and teaching skills. Ultimately, student teachers will benefit from our pedagogical as well as philosophical focuses on teacher preparation. As a matter of fact, student teachers did become aware of the importance of collaboration in dialogic discussions oriented towards bringing out lesson objectives. Just as Jane's reflection shows how she values this experience, the finding here might be able to offer a wider perspective on the issue from student teachers' point of view:

Teamwork is also vital to the success of the PE programme. Translated into the school setting, this means materials should be pooled and ideas freely "bandied around". Group synergy should be maximally utilised to tap the potential for new teaching ideas. In short, no teacher should stand alone. He or she should function as an autonomous unit, connected to the large framework and sharing its brad objectives, but also departing from the norm by blazing trails in the educational filed for others to follow.

Secondly, what really matters is that student teachers who have gone through the PE programme have learned something that they believe will be helpful to their future 
career development. As Betty wrote in her reflective journal No. 3 (Final Review), the last of the three journal assignments as part of the assessment for the course, she seemed to have better understood the value of PE. Her dedication and commitment to the profession were also revealed through her conscientious mental effort to remain in the profession and perform well. She quoted "Henry James, 1913" to show her determination to be an effective teacher.

To believe in a child is to believe in the future. Through their aspirations they will save the world. With the combined knowledge the turbulent seas of hate and injustice will be calmed. They will champion the causes of life's underdogs, forging a society without class discrimination. They will supply humanity with music and beauty as it has never known. They will endure. Towards these ends I pledge my life's work. I will supply the children with tool and knowledge to overcome the obstacles. I will pass on the wisdom of my years and temper it with patience. I shall impact in each child the desire to fulfil his or her dream. I shall teach. (Henry James, 1913)

Indeed, one may suggest that what the student teacher has written down is only a kind of fantasy, as many beginning teachers tend to idealise their career in this way. However, when we see a beginning teacher showing her warmth and enthusiasm for teaching based on her preliminary teaching experience, we can be assured that the enterprise of successful teaching is already half guaranteed. This is because in learning how to become teachers student teachers' emotions are equally related to their identities in terms of looking at who they are in the teaching profession (Clarke, 2008; Ria et al., 2003).

Thirdly, from the point of view of teacher development, we can conclude that preservice teachers who lack first-hand experience and direct contact with pupils can be inducted gradually to the real classroom situations through a sheltered approach such as our PE. By virtue of PE's direct relevance to pedagogy and to its real nature, student- teachers take it more seriously than "micro-teaching", which was once adopted on our training programme. This PE exposure seemed to have created a bridge between theory and practice and the student teachers were enlightened with new ideas in dealing with contingencies.

Of course, though not really a great concern here, we did find that student teachers as individuals demonstrated differences in the amount of input they offered to the group discussion of which they were a part. This inequity in contribution suggests differences in student teachers' inclinations towards group discussion, resulting in interesting interaction patterns. In a sense, some evidence was found that lends support to what has been reported in the literature on classroom interaction discourse (Basturkmen, 2003; Berry, 1981; Li et al., 2020; Stokoe, 2000).

Initial teacher-education is really pre-service preparation in its real sense, as student teachers have never been fully prepared in any way that would familiarise them with the principles of learning and teaching as well as the school context, whose essential parts entail pupil characteristics, class dynamics, and school culture. Student-teachers' understanding of these factors surely plays an important part in their transition and repositioning process, especially their role change from student teachers to that of full 
teachers. PE has provided such an interface for them to establish linkages between what they have gained from teaching and the training programme they undergo.

PE is limited in that it is conducted within a six-week period. However, given that PE has been functioning as a replacement of "micro-teaching" which preceded it in NIE and the results reported here seem to suggest that PE is a platform where student teachers are given more opportunities to have direct contact with real-life pupils, the PE experience seems to be able to make teaching more pertinent to student teachers' professional lives. It goes without saying that much awaits further investigation.

Lieberman and Miller (2000) have identified seven transitions that are needed by student teachers to make "the new social realities of teaching." These range from individualism to professional community, from teaching at the centre to learning at the centre, from technical work to enquiry, from control to accountability, from managed work to leadership, from classroom concerns to whole school concerns, and from a weak knowledge base to a stronger, broader one. It follows from the above that there is now a greater demand for better quality teachers and their role is going to change in profound ways. Indeed, these are important elements that should not be forgotten when we examine initial teacher preparation.

Reynolds (1992) states that beginning teachers, including, of course, those receiving training, are supposed to have four characteristics, or at least, they should be equipped with such characteristics after completing their training at a teacher training agency. They should have: 1) knowledge of the subject matter; 2) disposition to find out about students and schools and the skills to do so; 3) knowledge of strategies, techniques and tools to create and sustain a learning environment/community and the ability to employ the above; and 4) knowledge of content specific pedagogy. In this sense, a majority of the student teachers under study attempted at moving in this direction.

Therefore, in initial teacher education, it is pivotal that some of the ideas Liberman and Miller (2000, 2004) and Reynolds (1992) have listed should be taken into consideration. This approach to thinking about initial teacher education is also one of the bases upon which changes in teacher education have happened. Furlong and Maynard (1995) report that student teachers usually go through stages in learning to become teachers. These can range from early idealism, personal survival, dealing with difficulties, hitting a plateau and moving on. In this developmental model of teacher professional knowledge growth, new teachers tend to focus on mastering the procedural knowledge necessary to maintain classroom control and discipline before their attention is given to they teach and how students learn (see also Fuller, 1969; Fuller \& Brown, 1975). Findings from our study lend support to Fuller and his colleagues' observation. Several other scholars have recently stressed the importance of learning through collaboration (Fairbanks \& LaGrone, 2006; Musanti \& Pence, 2010). It seems that due to their strong concern for their own survival in the lessons, the student teachers' discussion lacked an overview of lesson structures; therefore, the connectedness of the episodes in the lessons was not given sufficient attention. Instead, the lessons were treated as separate episodes, without ample awareness of pupils, the central participants of the classroom process. This kind of survival strategy focused too much on "scripting their performance" as if to entertain pupils or keep them busy. Due to their excessive preparation for the mundane aspects of teaching, little focus was placed on pupil interaction, resulting in general, discrete and low-level concerns over 
classroom procedures. This is in a way resonates what Albright and Kramer-Dahl (2009) have found out about even among relatively more experienced teachers in Singapore. Kramer-Dahl (2008) has also expressed concerns about the system in which English teachers work to rigidly interpret the syllabus. Burn and associates (Burn, Hagger, Mutton, \& Everton, 2000) have argued for looking at beginning teachers "beyond concerns about self" because beginning teachers' thinking is more complicated than just concerns about self. Some of the data seem to lend support to their findings.

Nevertheless, it can be argued that the student teachers' concerns over their very own existence in the classroom may not be a bad thing as such. For example, Kagan (1992) argues that this may be beneficial to new teachers in that the procedural knowledge they have enables them to adapt and reconsider their idealised images of teachers and teaching so that they are more in tune with the realities of classroom life (see also Johnson, 1999). With the growth and automatisation in their procedural knowledge and a better understanding of their pupils, they will be better able to reconceptualise the content they are expected to teach with their pupils as their focus. Chaliès, Ria, Bertone, Trohel, and Durand (2004) found interesting interactions between preservice and cooperating teachers in relation to knowledge construction during post-lesson interviews. It can be ascertained that learning in groups is quite a productive way of learning how to teach (van Schaik et al., 2019). They will also thus be able to develop a repertoire of more reasoned instructions to inform their own classroom practices.

\section{Conclusion}

The study was set up to investigate student-teachers' interaction patterns in negotiations for knowledge-construction in order to become knowers of the field of teaching while they were learning how to teach English in an initial teacher education programme. Our analysis of the data shows that these student-teachers were more concerned about surviving the first lesson than about promoting pupil learning in their very process of constructing knowledge about what language teaching actually meant to them. The stronger peers' dominance in the discussion process was taken for granted, suggesting that learning took place in a mutually beneficial and constructive manner and that student teachers' willingness to cooperate and readiness to express themselves were indicative of their intention to maintain group cohesion and dynamics. These, in turn, are necessary prerequisites for student teachers to become collaborative and reflective practitioners. Such data indicate that if they were interested in becoming better teachers once they assumed the role in real classrooms, they would be concerned more about developing lesson objectives focusing on learning-centred interaction for effective language learning, as our data already showed that they were concerned about pupil learning as well as their own survival in learning how to teach. These findings have wider implications for initial teacher education programmes, where the teaching practicum component is done in a micro-teaching setting, which is very different from one that houses a live student body that a student-teacher has to face. Because of the interesting findings, we think that those initial language teacher education programmes might find it useful to try the PE programme that we investigated in this study and, if necessary, make modifications to suit the local context so that student-teachers will be scaffolded to have a first-hand experience in learning how to teach in a real classroom (Nunan \& Richards, 2015). 


\begin{abstract}
Abbreviations
CS: Curriculum subjects; CT: Cooperating teachers; EFL: English as a foreign language; IES: Institute of Education Singapore; L1: First language; L2: Second language; NIE: National Institute of Education (Singapore); NTU: Nanyang Technological University (Singapore); PE: Pupil experience; SE: School experience; SM: School mentors
\end{abstract}

\title{
Acknowledgements
}

We are obliged to the student-teachers, who voluntarily participated in this study anonymously and gave permission for us to use the transcribed dialogic discussion as data in this study. We are indebted to Dr Rita Skuja-Steele for her advice in our execution of the Pupil Experience Programme. Her expertise in teacher education, as evidenced in her Pupil Experience Workbook, and her wisdom in sifting and scrutinising the data, have helped us to bring to the fore key issues surfaced in the data we collected. We hereby record our gratitude, which is in fact a tribute to her contribution to language teacher education in Singapore.

We have written our paper ourselves, without resorting to any editorial service, so the requirement regarding this item is "not applicable".

\section{Authors' contributions}

Lawrence Jun Zhang conceptualised the design of the study, collected the data, and wrote the first draft. Donglan Zhang helped with data processing and analysis. Both authors revised the subsequent versions of the manuscript prior to its submission. They both read and approved the final manuscript.

\section{Authors' information}

Lawrence Jun Zhang, PhD, is Professor of Linguistics-in-Education and Associate Dean for the Faculty of Education \& Social Work, University of Auckland, New Zealand. His publications on students' L2 reading and writing development and language teacher education have appeared in Applied Linguistics Review, Modern Language Journal, TESOL Quarterly, Language Awareness, Discourse Processes, Reading and Writing, Reading and Writing Quarterly, RELC Journal, System, Journal of Second Language Writing, Teachers and Teaching, Australian Journal of Teacher Education, Language and Education, Language, Culture and Curriculum, among others. He is Co-Chief-editor for System and Associate Editor for Frontiers in Psychology, and an editorial board member for Applied Linguistics Review, Journal of Second Language Writing, Metacognition \& Learning, Chinese Journal of Applied Linguistics, and RELC Journal. He was honoured by the TESOL International Association (USA) in 2016 with the award of "50 at 50" that acknowledged "50 Outstanding Leaders" in the field around the world. He has also served as a member of the Board of Directors of the Association for three years.

Email: lj.zhang@auckland.ac.nz

Donglan Zhang has earned her BA in English Language Education from Shanghai International Studies University, China and MA in Applied Linguistics from the National Institute of Education (NIE) of Nanyang Technological University, Singapore. After working as a lecturer in the English Language and Literature Academic Group for almost 8 years, she left NIE to join the Faculty of Education of The University of Auckland, New Zealand, as a Senior Tutor. Her work currently is mainly concerned with advising students in academic literacies, especially those who need academic English language support. She has published in journals such Asian Englishers, Language Awareness, as well co-authored chapters in edited books published by Springer Nature, Wiley, Pearson Education, among others. Her research interests are in learner metacognition, research methods, language teacher education and students' academic English language development.

Email: Donglan.zhang@auckland.ac.nz

\section{Funding}

No funding was obtained for this research.

\section{Availability of data and materials}

The study reported in this paper is a qualitative study, where the original data are presented as they are. It is the only and main paper where such data are used.

\section{Competing interests}

The are no financial and non-financial competing interests in relation to this manuscript.

\section{Received: 2 October 2020 Accepted: 22 October 2020}

Published online: 04 December 2020

\section{References}

Albright, J., \& Kramer-Dahl, A. (2009). The legacy of instrumentality in policy and pedagogy in the teaching of English: The case of Singapore. Research Papers in Education, 24(2), 201-222.

Barkhuizen, G. (2019). Teacher identity. In S. Walsh, \& S. Mann (Eds.), The Routledge handbook of English language teacher education (pp. 536-552). New York: Routledge.

Basturkmen, H. (2003). So what happens when the tutor walks in? Some observations on interaction in a university discussion group with and without the tutor. Journal of English for Academic Purposes, 2(1), 21-33.

Benesch, S. (2017). Emotions and English language teaching: Exploring teachers' emotion labor. New York: Routledge.

Berry, M. (1981). Systemic linguistics and discourse analysis: A multilayered approach to exchange structure. In M. Coulthard, \& M. Montgomery (Eds.), Studies in discourse analysis (pp. 120-145). London: Routledge.

Borg, S. (2019). Language teacher cognition: Perspectives and debates. In X. Gao (Ed.), Second handbook of English language teaching (pp. 129-145). Cham: Springer Nature.

Burn, K., Hagger, H., Mutton, T., \& Everton, T. (2000). Beyond concerns with self: The sophisticated thinking of beginning teachers. Journal of Education for Teaching, 26(3), 259-278. 
Burn, K., Hagger, H., Mutton, T., \& Everton, T. (2003). The complex development of student teachers' thinking. Teachers and Teaching, 9(4), 309-331.

Chaliès, S., Ria, L., Bertone, S., Trohel, J., \& Durand, M. (2004). Interactions between preservice and cooperating teachers and knowledge construction during post-lesson interviews. Teaching and Teacher Education, 20(8), 765-781.

Chamot, A. U. (2005). Language learning strategy instruction: Current issues and research. Annual Review of Applied Linguistic, $25,112-130$.

Clarke, M. (2008). Language teacher identities: Co-constructing discourse and community. Buffalo: Multilingual Matters.

Cohen, A., \& Macaro, E. (2007). Language learning strategies: 30 years of research and practice. Oxford: Oxford University Press.

Coulthard, M., \& Brazil, D. (1992). Exchange structure. In M. Coulthard (Ed.), Advances in discourse analysis (pp. 50-78). London: Routledge.

De Costa, P. I., \& Norton, B. (2017). Introduction: Identity, transdisciplinarity, and the good language teacher. Modern Language Journal, 101(s1), 3-14.

Deng, Z. (2004). Beyond teacher training: Singaporean teacher preparation in the era of new educational initiatives. Teaching Education, 15(2), 159-173.

Deng, Z. (2007). Transforming the subject matter: Examining the intellectual roots of pedagogical content knowledge. Curriculum Inquiry, 37(3), 279-295.

Deng, Z., \& Gopinathan, S. (2003). Continuity and change in conceptual orientations for teacher preparation in Singapore: Challenging teacher preparation as training. Asia-Pacific Journal of Teacher Education, 31(1), 51-65.

Deng, Z., \& Gopinathan, S. (2006). The complicity of medium of instruction policies: Functions and hidden agendas. Journal of Curriculum Studies, 38(5), 609-622.

Dikilitaş, K., \& Hanks, J. (Eds.) (2019). Developing language teachers with exploratory practice. Cham: Palgrave Macmillan.

Edwards, A., \& Mutton, T. (2007). Looking forward: Rethinking professional learning through partnership arrangements in initial teacher education. Oxford Review of Education, 33(4), 503-519.

Ellis, D. G. (1999). Research on social interaction and the micro-macro issue. Research on Language and Social Interaction, $32(1-2), 31-40$.

Fairbanks, C. M., \& LaGrone, D. (2006). Learning together: Constructing knowledge in a teacher research group. Teacher Education Quarterly, 33(3), 7-25.

Farrell, T. S. (2008). Critical incidents in ELT initial teacher training. ELT Journal, 62(1), 3-10.

Farrell, T. S. (2015). Reflective language teaching: From research to practice. London: Bloomsbury.

Farrell, T. S. C. (2003). Learning to teach English language during the first year: Personal issues and challenges. Teaching and Teacher Education, 19(1), 95-111.

Fuller, F. F. (1969). Concerns for teachers: A developmental conceptualization. American Educational Review Journal, 6(2), 207226.

Fuller, F. F., \& Brown, O. (1975). Becoming a teacher. In K. Ryan (Ed.), Teacher education: The seventy-fourth yearbook of the National Society for the Study of Education (pp. 25-52). Chicago: University of Chicago Press.

Furlong, J., \& Maynard, T. (1995). Mentoring student teachers. London: Routledge.

Furlong, J., \& Maynard, T. (2012). Mentoring student teachers: The growth of professional knowledge. London: Routledge.

Gao, X. L., \& Zhang, L. J. (2020). Teacher learning in difficult times: Examining foreign language teachers' cognitions about online teaching to tide over COVID-19. Frontiers in Psychology, 11(49653), 1-14 https://doi.org/10.3389/fpsyg.2020.549653.

Golombek, P., \& Johnson, K. E. (2004). Narrative inquiry as a mediational space: Examining emotional and cognitive dissonance in second language teachers' development. Teachers and Teaching, 10(2), 307-327.

Hagger, H., Burn, K., Mutton, T., \& Brindley, S. (2008). Practice makes perfect? Learning to learn as a teacher. Oxford Review of Education, 34(2), 159-178.

Hoey, M. (1992). Some properties of spoken discourse. In R. Bowers, \& C. Brumfit (Eds.), Applied linguistics and language teaching (pp. 65-84). London: Modern English Publications/British Council.

Jiang, A. L., Zhang, L. J., May, S., \& Qin, L. T. (2020). Understanding novice teachers' perceived challenges and needs as a prerequisite for English curriculum innovation. Language, Culture and Curriculum, 33(1), 15-31.

Johnson, K. E. (1999). Understanding language teaching: Reasoning in action. Boston: Heinle \& Heinle.

Johnson, K. E. (2007). Tracing teacher and student learning in teacher-authored narratives. Teacher Development, 11(2), 1-14.

Kagan, D. M. (1992). Professional growth among pre-service and beginning teachers. Review of Educational Research, 62(2), 129-169.

Kagan, S., \& Robertson, L. (1993). An introduction to cooperative learning structures. San Juan Capistrano: Kagan.

Korhonen, A. M., Ruhalahti, S., \& Veermans, M. (2019). The online learning process and scaffolding in student teachers' personal learning environments. Education and Information Technologies, 24(1), 755-779.

Kramer-Dahl, A. (2008). Negotiating what counts as English language teaching: Official and enacted curriculum in two Singaporean classrooms. Research Papers in Education, 23(2), 83-107.

Li, H. H., Zhang, L. J., \& Parr, J. M. (2020). Small-group student talk before individual writing in tertiary English writing classrooms in China: Nature and insights. Frontiers in Psychology, 11(570575), 1-16 https://doi.org/10.3389/fpsyg.2020. 570565.

Liberman, A., \& Miller, L. (2004). Teacher leadership. San Francisco: Jossey-Bass.

Lieberman, A., \& Miller, L. (2000). Teaching and teacher development: A new synthesis for a new century. In R. S. Brandt (Ed.), Education in a new era: ASCD yearbook 2000 (pp. 47-66). Alexandria: ASCD.

Lineel, P., Gustavsson, L., \& Juvonen, P. (1988). Interactional dominance in dyadic communication: A presentation of initiativeresponse analysis. Linguistics, 26(4), 415-442.

Loh, J., \& Hu, G. (2019). Teacher education in Singapore. In G. Noblit (Ed.), Oxford research encyclopedia of education (pp. 122). Oxford: Oxford University Press.

Luke, A., Freebody, P., Lau, S., \& Gopinathan, S. (2005). Towards research-based innovation and reform: Singapore schooling in transition. Asia Pacific Journal of Education, 25(1), 5-28.

Macaro, E. (2006). Strategies for language learning and for language use: Revising the theoretical framework. Modern Lanquage Journal, 90(3), 320-337.

Miles MB, \& Huberman AM. (1994). Qualitative data analysis (2nd ed. ). Thousand Oaks: Sage. 
Musanti, S. I., \& Pence, L. (2010). Collaboration and teacher development: Unpacking resistance, constructing knowledge, and navigating identities. Teacher Education Quarterly, 37(1), 73-89.

Nunan, D., \& Richards, J. C. (2015). Language learning beyond the classroom. New York: Routledge.

Orland, L. (2001). Learning to mentor as learning a second language of teaching. Cambridge Journal of Education, 31(1), 5368.

Orland-Barak, L. (2002). What's in a case? What mentors' cases reveal about the practice of mentoring. Journal of Curriculum Studies, 34(4), 451-468.

Oxford, R. L. (1997). Cooperative learning, collaborative learning and interaction: Three communicative strands in the language classroom. Modern Language Journal, 81(4), 443-456.

Oxford, R. L. (2017). Teaching and researching language learning strategies: Self-regulation in context. New York: Routledge.

Pittman, J. (1999). The historical and emergent enactment of identity in language. Research on Language and Social Interaction, 32(1), 111-117.

Rahimi, M., \& Zhang, L. J. (2015). Exploring non-native English-speaking teachers' cognitions about corrective feedback in teaching English oral communication. System, 55, 111-122. https://doi.org/10.1016/.jsystem.2015.09.006.

Reeves, J. (2009). Teacher investment in learner identity. Teaching and Teacher Education, 25, 34-41.

Reynolds, A. (1992). What is a competent beginning teacher? A review of the literature. Review of Educational Research, 62(1), $1-35$.

Ria, L., Seve, C., Saury, J., Theureau, J., \& Durand, M. (2003). Beginning teachers' situated emotions: A study of first classroom experiences. Journal of Education for Teaching, 29(3), 219-233.

Richards, J. C. (1998). Beyond training: Perspectives on language teacher education. Cambridge: Cambridge University Press.

Richards, J. C. (2008). Second language teacher education today. RELC Journal, 39(2), 158-176.

Richards, J. C. (2020). Exploring emotions in language teaching. RELC Journal, 51(3), 1-15.

Richardson, V. (1999). Teacher education and the construction of meaning. In G. Griffin (Ed.), The education of teachers (pp. 145-166). Chicago: University of Chicago Press.

Ruhalahti, S., Korhonen, A. M., \& Rasi, P. (2017). Authentic, dialogical knowledge construction: A blended and mobile teacher education programme. Educational Research, 59(4), 373-390.

Rytivaara, A., \& Kershner, R. (2012). Co-teaching as a context for teachers' professional learning and joint knowledge construction. Teaching and Teacher Education, 28(7), 999-1008.

Silver, R. E., \& Bokhorst-Heng, W. D. (2016). Overarching themes, bilingual dreams and multilingual landscapes: Quadrilingual education in Singapore. In R. E. Silver, \& W. D. Bokhorst-Heng (Eds.), Quadrilingual education in Singapore (pp. 3-19). Singapore: Springer.

Sinclair, J., \& Coulthard, M. (1992). Towards an analysis of discourse. In M. Coulthard (Ed.), Advances in discourse analysis (pp. 50-78). London: Routledge.

Skuja-Steele, R. (2004). The pupil experience workbook. Singapore: National Institute of Education.

Soreide, G. E. (2006). Narrative construction of teacher identity: Positioning and negotiation. Teachers and Teaching, 12, 527547.

Stokoe, E. H. (2000). Constructing topicality in university students' small-group discussion: A conversation-analytic approach. Language and Education, 14(3), 184-203.

Trent, J. (2012). Becoming a teacher: The identity construction experiences of beginning English language teachers in Hong Kong. Australian Educational Researcher, 39(3), 363-383.

Turner, K., \& Turvey, A. (2002). The space between shared understandings of the teaching of grammar in English and French to year 7 learners: Student teachers working collaboratively. Language Awareness, 11(2), 100-112.

van Schaik, P., Volman, M., Admiraal, W., \& Schenke, W. (2019). Approaches to co-construction of knowledge in teacher learning groups. Teaching and Teacher Education, 84, 30-43.

Varghese, M., Morgan, B., Johnston, B., \& Johnson, K. A. (2005). Theorizing language teacher identity: Three perspectives and beyond. Journal of Language, Identity, and Education, 4, 21-44.

Vygotsky, L. S. (1987). Thinking and speech. In R. Rieber, \& A. Carton (Eds.), N. Minick Trans. L. S. Vygotsky, Collected works (vol. 1, pp. 243-285). New York: Plenum.

Yuan, R., \& Zhang, L. J. (2020). Teacher metacognitions about identities: Case studies of four expert language teachers in China. TESOL Quarterly, 54(4), 870-899.https://doi.org/10.1002/tesq.561.

Zembylas, M. (2003). Emotions and teacher identity: A poststructural perspective. Teachers and Teaching, 9(3), 213-238.

Zhang, D., \& Zhang, L. J. (2019). Metacognition and self-regulated learning (SRL) in second/foreign language teaching. In X. Gao (Ed.), Second handbook of English language teaching (pp. 1-11). Cham: Springer Nature.

Zhang, L. J. (2003). Research into Chinese EFL learner strategies: Methods, findings and instructional issues. RELC Journal, 34(3), 284-322.

Zhang, L. J. (2004a). Interpreting continuity and change in secondary school English-language teacher education in Singapore. CELEA Journal, 27(4), 309-317.

Zhang, L. J. (2004b). Reforming a teacher education program for PRC EFL-teachers in Singapore: Sociocultural considerations and curriculum evolution. International Journal of Educational Reform, 13(3), 223-252.

Zhang, L. J. (2016). Reflections on the pedagogical imports of western practices for professionalizing ESL/EFL writing and writing-teacher education. Australian Review of Applied Linguistics, 39(3), 203-232.

Zhang, L. J., \& Ben, S. S. (2014). Preface: Toward a global understanding of local initiatives in language teaching and teacher education: Global rules, local roles. In S. B. Said, \& L. J. Zhang (Eds.), Language teachers and teaching: Global perspectives, local initiatives (pp. xviii-xxx). New York: Routledge.

Zhang, L. J., \& Qin, T. L. (2018). Validating a questionnaire on EFL writers' metacognitive awareness of writing strategies in multimedia environments. In A. Haukås, C. Bjørke, \& M. Dypedahl (Eds.), Metacognition in language learning and teaching (pp. 157-179). London: Routledge.

Zhang, L. J., Thomas, N., \& Qin, T. L. (2019). Language learning strategy research in System: Looking back and looking forward. System, 84, 87-93. 
Zhang, L. J., \& Zhang, D. (2015). Identity matters: An ethnography of two non-native English-speaking teachers (NNESTS) struggling for legitimate professional participation. In Y. L. Cheung, S. Ben Said, \& K. Park (Eds.), Advances and current trends in language teacher identity research (pp. 116-131). New York: Routledge.

Zhang, L. J., \& Zhang, D. (2018). Metacognition in TESOL: Theory and practice. In J. I. Liontas, \& A. Shehadeh (Eds.), The TESOL encyclopedia of English language teaching, Vol. II: Approaches and methods in English for speakers of other languages (pp. 682-792). Hoboken: Wiley-Blackwell https://doi.org/10.1002/9781118784235.eelt0803.

\section{Publisher's Note}

Springer Nature remains neutral with regard to jurisdictional claims in published maps and institutional affiliations.

Submit your manuscript to a SpringerOpen ${ }^{\odot}$ journal and benefit from:

- Convenient online submission

- Rigorous peer review

- Open access: articles freely available online

- High visibility within the field

- Retaining the copyright to your article

Submit your next manuscript at $\boldsymbol{\nabla}$ springeropen.com 